\title{
SOIL EROSION VULNERABILITY IN THE VERDE RIVER BASIN, SOUTHERN MINAS GERAIS
}

\author{
Vulnerabilidade dos solos à erosão hídrica na bacia \\ hidrográfica do Rio Verde, sul de Minas Gerais
}

\author{
Vinícius Augusto de Oliveira1, Carlos Rogério de Mello², \\ Matheus Fonseca Durães ${ }^{2}$, Antônio Marciano da Silva²
}

\begin{abstract}
Soil erosion is one of the most significant environmental degradation processes. Mapping and assessment of soil erosion vulnerability is an important tool for planning and management of the natural resources. The objective of the present study was to apply the Revised Universal Soil Loss Equation (RUSLE) using GIS tools to the Verde River Basin (VRB), southern Minas Gerais, in order to assess soil erosion vulnerability. A annual rainfall erosivity map was derived from the geographical model adjusted for Southeastern Brazil, calculating an annual value for each pixel. The maps of soil erodibility (K), topographic factor (LS), and use and management of soils (C) were developed from soils and their uses map and the digital elevation model (DEM) developed for the basin. In a GIS environment, the layers of the factors were combined to create the soil erosion vulnerability map according to RUSLE. The results showed that, in general, the soils of the VRB present a very high vulnerability to water erosion, with $58.68 \%$ of soil losses classified as "High" and "Extremely High" classes. In the headwater region of VRB, the predominant classes were "Very High" and "Extremely High" where there is predominance of Cambisols associated with extensive pastures. Furthermore, the integration of RUSLE/GIS showed an efficient tool for spatial characterization of soil erosion vulnerability in this important basin of the Minas Gerais state.
\end{abstract}

Index terms: Revised Universal Soil Loss Equation (RUSLE), GIS, erosion, basin management.

\section{RESUMO}

A erosão do solo é um dos processos de degradação ambiental mais significativos. O mapeamento e avaliação da vulnerabilidade do solo à erosão é uma importante ferramenta para o planejamento e gestão dos recursos naturais. O presente trabalho teve como objetivo a aplicação da Equação Universal de Perda de Solo Revisada (R-USLE) com utilização de um SIG, na bacia do Rio Verde, sul de Minas Gerais, a fim de avaliar a vulnerabilidade dos solos à erosão hídrica. O mapa do fator erosividade da chuva (R) foi desenvolvido a partir de um modelo geográfico desenvolvido para o Sudeste do Brasil, sendo obtido em nível de pixel. Os fatores erodibilidade dos solos (K), fator topográfico (LS) e uso e manejo (C) foram obtidos, respectivamente, de mapas de solos e de seus usos e modelo digital de elevação (MDE) em ambiente SIG. Os mapas foram dos fatores foram combinados por meio de álgebra de mapas, originando o mapa de vulnerabilidade dos solos à erosão hídrica. Os resultados mostraram que, em geral, os solos da bacia do rio Verde apresentam vulnerabilidade muito alta à erosão hídrica, apresentando 58,68\% da perda de solo nas classes "Alta" a "Extremamente Alta". Nas regiões de cabeceira, as classes predominantes foram "Muito Alta" e "Extremamente Alta". Valores elevados de perda de solo foram predominantes em regiões de Cambissolos cobertos por pastagens. Além disso, a integração RUSLE/GIS apresentou-se uma ferramenta eficiente para a predição da erosão nesta importante bacia hidrográfica do estado de Minas Gerais.

Termos para indexação: Equação Universal de Perda de Solo Revisada (RUSLE), SIG, erosão, manejo de bacias hidrográficas.

\section{INTRODUCTION}

Soil erosion is the main environmental impact that affects the state of Minas Gerais, with degradation and impoverishment of soils and reduction of surface water quality in basins. A quick and quite accurate method to qualitatively assess the erosive potential in a particular region is provided by application of predictive soil loss models, which consider the assets and liabilities of erosion factors.
The RUSLE (Revised Universal Soil Loss Equation) is considered a simple model for predicting soil erosion, in which the average annual long term soil losses is estimated with acceptable accuracy (Beskow, Mello; Norton, 2009). It is a model that is an evolution of the Universal Soil Loss Equation (USLE) model, as it considers upstream areas contributing to downstream surface runoff. Thus it is a model with better predictive ability than the USLE. In this regard, the topographic parameter gains a more grounded

\footnotetext{
${ }^{1}$ Universidade Federal de Lavras/UFLA-Departamento de Engenharia/DEG - Cx. P. 3037-37.200-000 - Lavras - MG - Brasil-viniciusaoliveira@yahoo.com.br 2Universidade Federal de Lavras/UFLA - Departamento de Engenharia/DEG - Lavras - MG - Brasil

Received in march 8, 2014 and approved in april 28, 2014
}

Ciênc. Agrotec., Lavras, v.38, n. 3, p.262-269, maio./jun., 2014 
scientific connotation, physically improving the model (Zhang et al. 2013).

The assessment of the vulnerability of soils to erosion on a large scale, like in basins, can be carried out with the RUSLE model as its topographic factor was reformulated, improving the representativeness of it in basin's scale (Ozsoy et al., 2008; Prasannakumar et al., 2012; Zhang et al., 2013). However, it requires the use of tools able to collect, store, manipulate and display spatial data (Durães; Mello, 2013). Therefore, a Geographical Information System (GIS) has been used, especially by applying the technique of map algorithms (Ozcan et al., 2008; Pradhan et al., 2012; Beskow; Mello; Norton, 2009). This technique has produced good results with the application of RUSLE, developing maps with the average spatial distribution of soil losses and its subsequent interpretation in the context of natural vulnerability.

In this context, the objective of this work was to implement the Revised Universal Soil Loss Equation (RUSLE), through map algorithms, to evaluate the natural vulnerability of soils to water erosion in the Verde River Basin (VRB) which is one of the most important hydrologic units of the southern Minas Gerais. The results of this study will allow the identification areas more susceptible to erosion in order to provide assistance for planning and management of natural resources in the basin.

\section{MATERIAL AND METHODS}

\section{Description of the study area}

The Verde River Basin (VRB) is located in South/ Southwest mesoregion of Minas Gerais state, between the latitudes of $21^{\circ} 30^{\prime} \mathrm{S}$ and $22^{\circ} 30^{\prime} \mathrm{S}$ and the longitudes of $44^{\circ} 40^{\prime} \mathrm{W}$ and $45^{\circ} 40^{\prime} \mathrm{W}$, with a drainage area of $4178 \mathrm{~km}^{2}$ and is part of the Water Resources Management Planning Unit (UPGRH) GD4 (Figure 1). The climate is classified as Cwa and Cwb. The former is predominant in most of

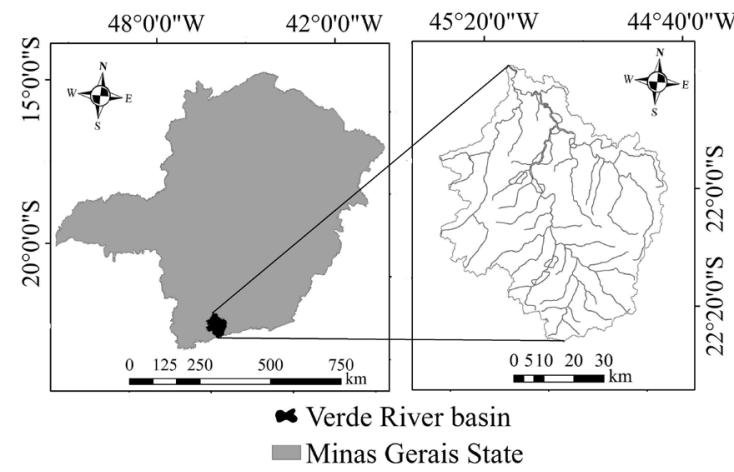

Figure 1 - Location of the VRB in the Minas Gerais state. the basin and the latter, in the Mantiqueira Range region and neighborhood (Viola et al., 2013). These climate types present two seasons well characterized by mild and rainy summer and cool and dry winter, with annual amount of rain ranging from 1100 to $2100 \mathrm{~mm}$.

\section{Revised Universal Soil Loss Equation (RUSLE)}

The Revised Universal Soil Loss Equation (RUSLE) was used in this study to estimate the average annual soil loss in the VRB through a GIS environment using map algorithms. RUSLE has the following structure:

\section{$\mathrm{A}=\mathrm{R} \times \mathrm{K} \times \mathrm{LS} \times \mathrm{C} \times \mathrm{P}$}

Where $\mathrm{A}$ is soil loss $\left(\mathrm{t} \mathrm{ha}^{-1} \mathrm{yr}^{-1}\right), \mathrm{R}$ the rainfall erosivity (MJ mm ha $\left.{ }^{-1} \mathrm{~h}^{-1} \mathrm{yr}^{-1}\right), \mathrm{K}$ the soil erodibility ( $\mathrm{t} \mathrm{h}$ $\mathrm{MJ}^{-1} \mathrm{~mm}^{-1}$ ); LS the topographic factor (dimensionless), $\mathrm{C}$ the soil use and management factor (dimensionless), $\mathrm{P}$ the soil conservation practice factor (dimensionless).

\section{Rainfall erosivity (R)}

The rainfall erosivity represents the potential of rain to cause erosion in an exposed and unprotected soil surface, whose physical definition is the product of rainfall kinetic energy and the maximum rainfall intensity in 30-minute consecutive $\left(\mathrm{EI}_{30}\right)$ (Wischmeier; Smith, 1978). Due to lack of detailed rainfall records, many authors correlate the $\mathrm{EI}_{30}$ with the Modified Fournier Index (MFI), whose rainfall erosivity value can be obtained based on monthly and annual precipitation data sets (Renard; Freimund, 1994).

Although the rainfall erosivity map can be generated based on geostatistical procedures (Mello et al., 2007), its use for map algorithm application can produce inaccurate estimates as this map is based on a class interval. It means that the users do not estimate a specific value for a given location (cells in this case), they simply have a special distribution of values without taking into account other physiographical properties of landscape such as continental and topographical properties (Mello et al., 2013). Thus, in most times, a unique rainfall erosivity value is used to represent the entire basin.

To overcome this, for obtaining the rainfall erosivity map we applied the multivariate geographical model proposed by Mello et al. (2013), which estimates the mean annual rainfall erosivity based on the latitude, longitude and altitude of each cell of the basin, characterizing $\mathrm{R}$ factor in a distributed manner. For that, a digital elevation model is required. The model 
for estimating the mean annual $\mathrm{R}$ value for Southeastern Brazil is given by:

$\mathrm{R}=-399433+420.49 \times \mathrm{A}-78296 \times \mathrm{LA}-0.01784 \mathrm{x}$

$\mathrm{A}^{2}-1594.04 \times \mathrm{LA}^{2}+195.84 \times \mathrm{LO}^{2}+17.77 \times \mathrm{LO} \times \mathrm{A}-$

$1716.27 \times \mathrm{LA} \times \mathrm{LO}+0.1851 \times \mathrm{LO}^{2} \times \mathrm{A}+0.00001002$

$x \mathrm{LO} \times \mathrm{A}^{2}+0.01364 \times \mathrm{LA}^{2}+0.01364 \times \mathrm{LA}^{2} \times \mathrm{LO}^{3}$

In which $\mathrm{R}$ is the average annual erosivity (MJ $\left.\mathrm{mm} \mathrm{ha}^{-1} \mathrm{yr}^{-1}\right), \mathrm{A}$ is the altitude (m), LA latitude and LO longitude, both in negative decimal degrees.

\section{Soil erodibility (K)}

The soil erodibility $(\mathrm{K})$ is intrinsic susceptibility of the soil to erosion, which is a function of its physical, chemical and pedologic characteristics of the soils, such as percentage of silt and sand, structure, permeability, organic matter, parental material and others (Ozsoy et al., 2012; Pradhan et al., 2012).

The $\mathrm{K}$ values applied in this study were extracted from the literature as this factor has been well studied and documented and are shown in table 1. The soils map is the reference to obtain the $\mathrm{K}$ factor map and we used that map developed by Minas Gerais State Foundation of the Environment (FEAM, 2010).

\section{Topographic factor (LS)}

This factor is used in the RUSLE considering the effects of topography on soil erosion. In addition, in this model, LS factor accounts for the effect of the flow accumulated in cells upstream to those downstream. The topographic factor, originally known as LS (Wischmeier; Smith, 1978), adapted to RUSLE, can be estimated by (Engel, 2003):

$$
\text { LS }=\left(\frac{[\text { Flow accumulation] [Cell size }]}{22.13}\right)^{0.4}\left(\frac{[\sin \text { (Slope) }]}{0.0896}\right)^{1.3}
$$

In which the accumulated flow and slope map were obtained from the digital elevation model (DEM) with a resolution of $30 \mathrm{~m}$, produced by interpolation of digitized topographic maps from Brazilian Institute of Geography and Statistics (IBGE).

\section{Soil use and management (C) and crop practices (P) factors}

The $\mathrm{C}$ factor is related to land cover and represents the relationship between soil loss from a land area cultivated under particular management and corresponding losses from land continuously maintained uncovered, considering the same conditions of slope and soil type (Beskow, Mello; Norton,
2009). This factor varies according to vegetation cover, ranging from 0 to 1 , where higher values represent greater disagregation of soils to rainfall impact and surface runoff.

The land use map was generated from images of the Landsat ETM+ sensor of 2005 and classified by the maximum likelihood method (Figure 2). The values of $\mathrm{C}$ used in this study (Table 2) were obtained from the literature. The factors "Bare Soil", "Urbanization" and "Water" were considered, respectively 1, 0 and 0 .

The $\mathrm{P}$ factor varies from 0 to 1 and expresses how the surface and management practices are able to reduce erosion. As most of the watershed shows no erosion control practices, the $\mathrm{P}$ factor was considered to be equal to 1 as suggested by Beskow, Mello and Norton, (2009), Ozsoy et al. (2012) and Silva, Montenegro and Santos (2012).

Figure 2 shows the basic maps (DEM, slope, soil type and soil use ) to obtain maps of the R, K, LS and CP factors.

\section{RESULTS AND DISCUSSION}

Figure $3 \mathrm{a}$ presents the mean annual rainfall erosivity map ( $\mathrm{R}$ factor) in the VRB, which had values ranging from 7,086 to $15,115 \mathrm{MJ} \mathrm{mm} \mathrm{ha}^{-1} \mathrm{yr}^{-1}$. Values greater than 9,000 MJ mm ha-1 $\mathrm{yr}^{-1}$ can be observed in the headwater region of VRB, specifically in the Mantiqueira Range region (southern VRB). These values are close to those obtained by Mello et al. (2012), who calculated values greater than $10,000 \mathrm{MJ} \mathrm{mm} \mathrm{ha}^{-1} \mathrm{yr}^{-1}$ for Mantiqueira Range region taking individual rainfall events from 2006 to 2012 as a reference. This behavior indicates that the orographic effect has a fundamental importance in the rainfall erosivity pattern. This assessment was possible due to the methodology adopted in this study which applied a geographical regression model for $\mathrm{R}$ estimates, avoiding the use a unique average value to represent the entire the basin.

The soil erodibility map (Figure $3 b$ ) is a reflection of the prevailing pedological units in the VRB (Cambisols), which covers almost $50 \%$ of the entire area. Soils with an incipient B horizon, such as Cambisols, are very susceptible to erosion because they present high content of silt, which may cause surface sealing of exposed soil, with a reduction water infiltration capacity, thus enabling the occurrence of surface runoff (Beskow, Mello; Norton,2009).

The spatial distribution of the LS factor (Figure 3c) showed almost $93 \%$ of the basin present values less than 10 , which represents a moderate vulnerability associated with the topography effect. In contrast, the remaining $7 \%$ represents areas with high potential for erosion, especially in headwater regions, as these areas present the greatest LS values. 
Table 1 - Soil erodibility values and their respective authors.

\begin{tabular}{ccc}
\hline Soil type & $\mathrm{K}\left(\mathrm{t} \mathrm{h}(\mathrm{MJ} \mathrm{mm})^{-1}\right.$ & Authors \\
\hline Argisol & 0.033 & Sá et al. (2004) \\
Oxisol (Latosol) & 0.01913 & Mannigel et al. (2002) \\
Cambisol & 0.0508 & Araújo Salviano and Neto (2011) \\
Fluvic Neosol & 0.042 & Ribeiro and Alves (2008) \\
Litholic Neosol & 0.0569 & Castro, Lemke-de-Castro and Lima (2011) \\
\hline
\end{tabular}
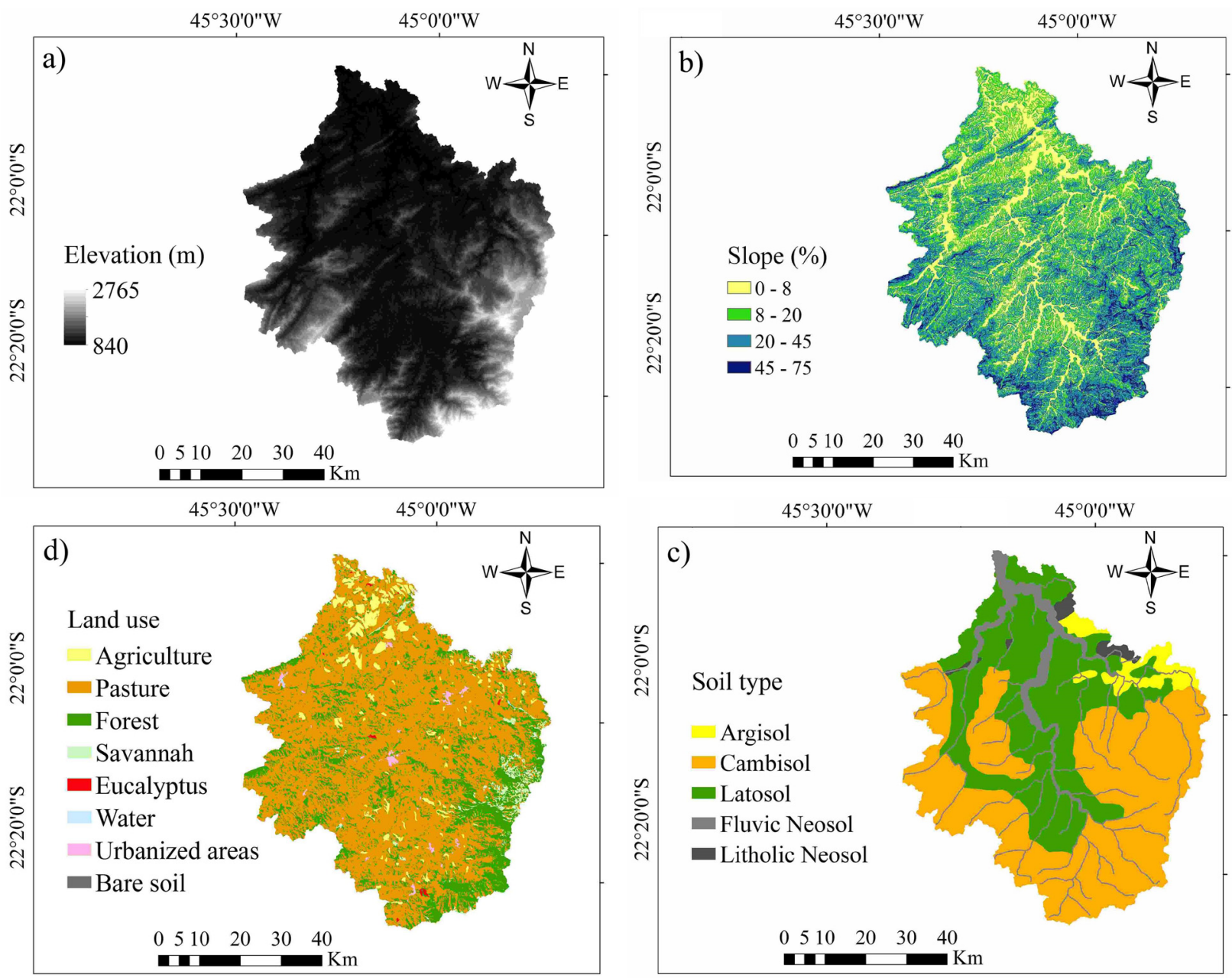

Figure 2 - Maps of Digital Elevation Model (DEM) (a), slope (b), soil type (c) and land use (d).

The spatial distribution of the soil erosion vulnerability in VRB is shown in figure 4, adapting the classification proposed by Beskow, Mello and Norton, (2009). This classification allows a qualitative classification of soil erosion vulnerability into classes ranging from "Slight" to "Extremely High". The interaction of the previously described factors with the type of vegetation is critical to understand the spatial distribution of soils erosion vulnerability in the basin. It's important to notice in figure 4 that in high altitudes and 
protected forested areas, the soils vulnerability is low, giving evidence to the importance of vegetation cover for soil protection facing the effects of the active erosion agent (rainfall). This feature can be verified in areas near the Mantiqueira Range (southern and southeastern regions of the VRB), in which the extent of soil loss was considerably lower compared to less steep and lower altitude areas.

On the other hand, areas where there is a predominance of agriculture and pasture had greater vulnerability, however, in lower part of the basin, values of soil loss are reduced due to the presence of Oxisols (Figure 2c), which have lower erodibility and therefore less soil erosion vulnerability.

In table 3, we can see that approximately $35.99 \%$ of the VRB area showed values between 0 and $10 \mathrm{tha}^{-1}$ $\mathrm{yr}^{-1}$, in which $24.17 \%$ could be classified as "slight" vulnerability. This result can be explained on the basis of the low values for LS and CP factors, especially in the lower regions of the basin. However, $58.68 \%$ of the basin showed soil losses greater than $15 \mathrm{t} \mathrm{ha}^{-1} \mathrm{yr}^{-1}$, characterizing these regions of VRB as "very high" vulnerability and a need to adopt conservation practices is warranted.

The results presented in table 4 refer to the variation of soil losses for each soil erosion vulnerability class and to each pedological unit. High soil losses values can be explained due to the combination of
Cambisols covered by extensive pasture. Soil erosion losses in Cambisols and Litholic Neosol accounted for $37.65 \%$ of total losses, where more than half of this value $(24.73 \%)$ occurred between "high" and "extremely high" vulnerability classes.

Soil losses in Oxisols accounted for $25.89 \%$ of total losses, however, most of these losses (12.57\%) occurred in conditions of low vulnerability. Areas with presence of Fluvic Neosols accounted for 33.69\% of soil losses. Even covering a significantly larger than the area of Fluvic Neosols, Oxisols had a lower soil loss rate, demonstrating the importance of the intrinsic soil attributes related to erosion susceptibility regarding the natural protection of soils facing the effects of erosive agents.

In addition, most of the soil losses in Fluvic Neosols occurred between "moderate to high" and "extremely high" vulnerability classes, representing $17.22 \%$ of the total soil losses (33.69\%). This behavior can be explained due to the combination of agriculture and Fluvic Neosols, especially in the lower region of the VRB, since the agriculture practices has high $\mathrm{CP}$ values and the Fluvic Neosol has a high erodibility.

Also, we can see that the soil types Cambisol, Latosol and Fluvic Neosol produced high soil losses rates in "high" and "extremely high" vulnerability classes, representing $49.50 \%$ of the total soil losses in the VRB.

Table 2 - Soil use and management values (C) applied to the study.

\begin{tabular}{cccc}
\hline Soil use & Area (\%) & C & Author \\
\hline Agriculture & 3.57 & 0.29 & Beskow, Mello and Norton, (2009) \\
Pasture & 45.40 & 0.09 & Ozsoy et al. (2012) \\
Forest & 47.36 & 0.01 & Beskow, Mello and Norton, (2009) \\
Savannah & 2.44 & 0.001 & Beskow, Mello and Norton, (2009) \\
Eucalyptus & 0.21 & 0.3 & Martins et al. (2010) \\
Water & 0.09 & 0 & \\
Urbanization & 0.52 & 0 & \\
Bare soil & 0.40 & 1 & \\
\hline
\end{tabular}



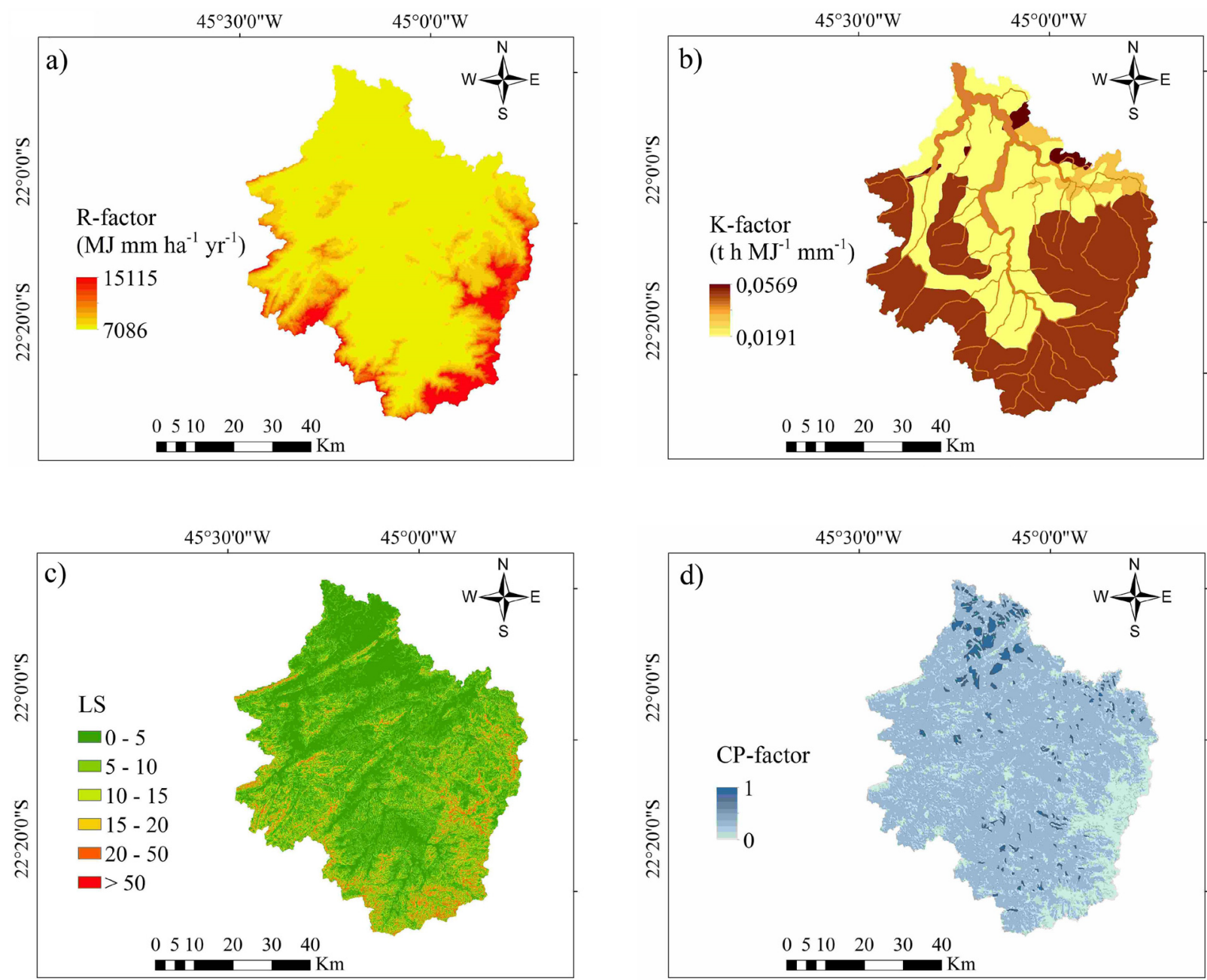

Figure 3 - Maps of the factors of RUSLE (R - a, K - b, LS - c and CP - d).

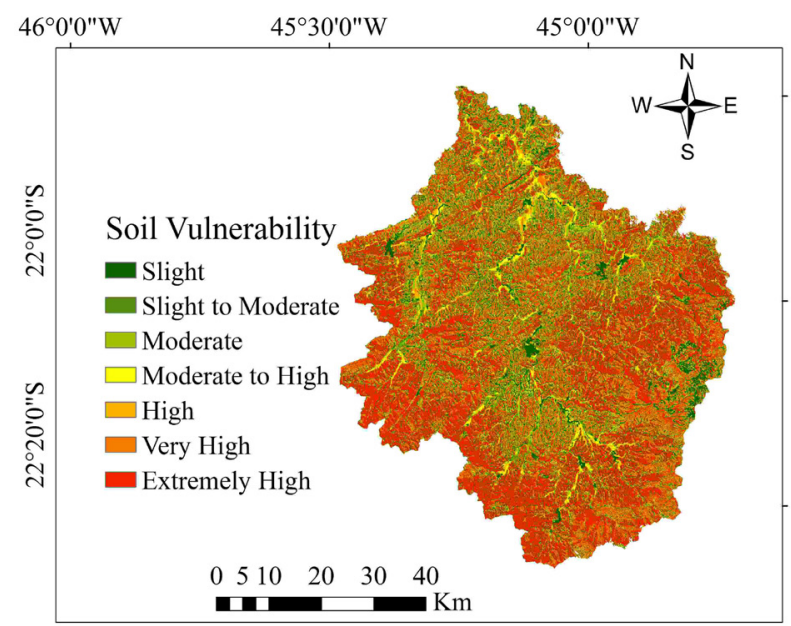

Figure 4 - Soil erosion vulnerability map for the VRB in southern Minas Gerais.

Ciênc. Agrotec., Lavras, v.38, n. 3, p.262-269, maio./jun., 2014 
Table 3 - Classification of the soil erosion vulnerability adapted from Beskow, Mello and Norton, (2009) as well as the percentage of the VRB area occupied for each classification proposed.

\begin{tabular}{ccc}
\hline Soil loss $\left(\mathrm{Mg} \mathrm{ha}^{-1} \mathrm{yr}^{-1}\right)$ & Vulnerability & Area (\%) \\
\hline $0-2.5$ & Slight & 24.17 \\
$2.5-5$ & Slight to Moderate & 4.99 \\
$5-10$ & Moderate & 6.83 \\
$10-15$ & Moderate to High & 5.33 \\
$15-25$ & High & 7.16 \\
$25-100$ & Very High & 26.87 \\
$>100$ & Extremely High & 24.65 \\
\hline
\end{tabular}

Table 4 - Variation of soil loss (\%) at different intervals of class and soil type.

\begin{tabular}{ccccccccc}
\hline \multirow{2}{*}{ Soil type } & \multicolumn{7}{c}{ Soil loss intervals $\left(\mathrm{Mg} \mathrm{ha}^{-1} \mathrm{yr}^{-1}\right)$} \\
\cline { 2 - 8 } & $0-2.5$ & $2.5-5$ & $5-10$ & $10-15$ & $15-25$ & $25-100$ & $>100$ & Total (\%) \\
\hline Argisol & 0.68 & 0.08 & 0.20 & 0.13 & 0.20 & 0.74 & 0.73 & 2.77 \\
Cambisol & 8.02 & 0.56 & 1.13 & 1.13 & 1.67 & 8.52 & 15.66 & 36.68 \\
Latosol & 6.72 & 2.07 & 2.28 & 1.49 & 2.23 & 7.90 & 3.18 & 25.89 \\
Fluvic Neosol & 8.50 & 2.25 & 3.18 & 2.54 & 2.98 & 9.45 & 4.79 & 33.69 \\
Litholic Neosol & 0.24 & 0.02 & 0.04 & 0.05 & 0.07 & 0.26 & 0.29 & 0.97 \\
\hline Total (\%) & 24.17 & 4.99 & 6.83 & 5.33 & 7.16 & 26.87 & 24.65 & 100 \\
\hline
\end{tabular}

\section{CONCLUSIONS}

The use of the RUSLE model integrated to GIS by means map algorithms showed to be an effective tool for assessing the soil erosion vulnerability in a basin's scale. The results also showed that, in general, the soils of the VRB have very high soil erosion vulnerability, with $58.68 \%$ of the soil losses classified as "High" to "Extremely High" classes. In the headwater regions, the predominant classes were "Very High" and "Extremely High". High soil losses values were predominant in areas with Cambisols covered by extensive pastures. These findings also indicate the need for implementation of conservation practices and soil management to reduce the soil erosion vulnerability in these areas.

\section{REFERENCES}

ARAÚJO, F. S.; SALVIANO, A. A. C.; NETO, M. R. H. Estimativa da erodibilidade de latossolos do Piauí. Scientia Plena. 7(10):1-6, 2011.
BESKOW, S.; MELLO, C.R.; NORTON, L. D. Soil erosion prediction in the Grande River Basin, Brazil using distributed modeling. Catena. 79(1):49-59, 2009.

CASTRO, W. J.; LEMKE-DE-CASTRO, M. L.; LIMA, J. O. et al. Erodibilidade de Solos do Cerrado Goiano.

Revista Agronegócios e Meio Ambiente. 4(2):305-320, 2011.

DURÃES, M. F.; MELLO, C. R. Groundwater recharge behavior based on surface runoff hydrographs in two basins of the Minas Gerais State. Revista Ambiente \& Água. 8(2):1-10, 2013.

ENGEL, B. Estimating soil erosion using RUSLE using Arcview. Purdue University, Indianapolis. 2003. Available at: <http://pasture.ecn.purdue.edu/ engelb/ agen526/gisrusle/gisrusle.html $>$. Accessed on 2 jul. 2013. 
FUNDAÇÃO ESTADUAL DO MEIO AMBIENTE. Mapa de solos do estado de Minas Gerais. Belo Horizonte: FEAM, 2010. Available at: $<$ http://www. feam.br/noticias/1/949-mapas-de-solos-do-estado-deminas-gerais $>$. Accessed on: 27 out. 2013.

MANNIGEL, A. R. et al. Fator erodibilidade e tolerância de perda dos solos do Estado de São Paulo. Acta Scientiarum. 24(5):1335-1340, 2002.

MARTINS, S. G. et al. Fator cobertura e manejo do solo e perdas de solo e água em cultivo de eucalipto e em Mata Atlântica nos Tabuleiros Costeiros do Estado do Espírito Santo. Scientia Forestalis. 38(87):517-526, 2010.

MELLO, C. R. et al. Erosividade mensal e anual da chuva no Estado de Minas Gerais. Pesquisa Agropecuária Brasileira. 42(4):537-545, 2007.

Sea surface temperature (SST) and rainfall erosivity in the Upper Grande River Basin, Southeast Brazil. Ciência e Agrotecnologia. 36(1):5359, 2012.

. Multivariate models for annual rainfall erosivity in Brazil. Geoderma. 202-203:88-102, 2013.

OZCAN, A. U. et al. Use of USLE / GIS technology integrated with geostatistics to assess soil erosion risk in different land uses of Indagi Mountain Pass - Çankiri, Turkey. Eviromental Geology. 53(8):1731-1741, 2008.

OZSOY, G. et al. Determination of soil erosion risk in the Mustafakemalpasa River Basin, Turkey, using the Revised Universal Soil Loss Equation, Geographic Information System, and Remote Sensing. Environmental Management. 50(4):679694, 2012.

PRADHAN, B. et al. Soil erosion assessment and its correlation with landslide events using remote sensing data and GIS: a case study at Penang Island, Malaysia.
Environmental Monitoring and Assessment. 184(2):715-27, 2012.

PRASANNAKUMAR, V. et al. Estimation of soil erosion risk within a small mountainous sub-watershed in Kerala, India, using Revised Universal Soil Loss Equation (RUSLE) and geo-information technology. Geoscience frontiers. 3(2):209-215, 2012.

RENARD, K. G.; FREIMUND, J. R. Using monthly precipitation data to estimate the R-factor in the revised USLE. Journal of Hydrology. 157(1-4):287-306, 1994.

RIBEIRO, L. S.; ALVES, M. G. Análise de suscetibilidade à erosão laminar no município de Campos dos Goytacazes / RJ através de técnicas de geoprocessamento. Estudos Geográficos. 6(1):89-100, 2008.

SÁ, M. A. C. et al. Estimativa da erodibilidade pela desagregação por ultra-som e atributos de solos com horizonte B textural. Pesquisa Agropecuária Brasileira. 39(7):691-699, 2004.

SILVA, R. M.; MONTENEGRO, S. M. G. L.; SANTOS, C. A. G. Integration of GIS and remote sensing for estimation of soil loss and prioritization of critical sub-catchments: a case study of Tapacurá catchment. Natural Hazards. 62(3):953-970, 2012.

VIOLA, M. R. et al. Applicability of the LASH Model for hydrological simulation of the Grande River Basin, Brazil. Journal of Hydrologic Engineering. 18(12):1639-1652, 2013.

WISCHMEIER, W. H.; SMITH, D. D. Predicting rainfall erosion losses: A guide to conservation planning. Washington: USDA, 1978. 58 p.

ZHANG, H. et al. Extension of a GIS procedure for calculating the RUSLE equation LS factor. Computers \& Geoscienses. 52(1):177-188, 2013. 